\title{
ANTISIPASI UMAT BERAGAMA TERHADAP TREND GOLOBALISASI DAN PEMBANGUNAN DI PROPINSI MALUKU (Studi Kasus di Kec. Teluk Ambon Baqula Kodya Ambon)
}

\section{Oleh : Pat. Badrun}

\section{PENDAHULUAN}

Studi ini beranjak pada masalah yang mengacu kepada tig pertany aan pokok y akni (1) Bagaimana respon masyarakat dan agama terhadap tantangan dan pengaruh trend globalisasi dewasa ini, (2) Bagaimana ke-ragaman latar belakang regional dan lokal berupa perbedaan geografis dan sosial budaya masyarakat Indonesia melahirkan perbedaan respon ; dan (3) Bagaimana berbagai kecenderungan respon tersebut mempunyai dampak terhadap proses pembangunan.

Sebagai studi kasus yang lebih bersifat eksploratif, maka tujuan penelitian ini ialah menemukan jawaban terhadap pertanyaan yang diajukan dalam/sebagai masalah tersebut di atas. Konkritnya, penelitian bertujuan untuk menemukan informasi yang menyangkut : (1) respon masyarakat dan agama terhadap trend globalisasi yang melanda masyarakat dewasa ini; (2) perbedaan-perbedaan respon sebagai akibat dari perbedaan latar belakang lokasi penelitian; dan (3) dampak dari respon tersebut terhadap proses pembangunan lokal.

Beberapa konsep yang digunakan dalam penelitian ini, seperti dirumuskan dalam disain, ${ }^{2)}$ perlu diberikan batasan arti yang lebih operasional.

Antisipasi diartikan sebagai upaya pemanfaatan potensi yang mewujud dalam pandangan, penilaian, sikap, dan tingkah laku terhadap masalah-masalah yang diperkirakan terjadi pada masa datang sehubungan dengan pengaruh globalisasi dewasa ini.

Respon diartikan sebagai pandangan, sikap, dan tingkah laku masyarakat (umat beragama) terhadap hal-hal yang terjadi dalam masyarakat dan berkembang menjadi masalah baru yang dirasakan menggeser nilai-nilai yang sudah ada. Respon dilakukan oleh seorang atau kelompok masyarakat, baik untuk mempertahankan diri maupun untuk memanfaatkan secara selektif nilainilai budaya luar.

Agama yang dimaksudkan dalam penelitian ini meliputi ajaran dan ide yang bersumber dari teks kitab suci dari masingmasing agama yang ada di Indonesia (dan memiliki penganut di lokasi penelitian) dalam bentuk pandangan, sikap, dan tindakan (dari pemeluk agama bersangkutan).

Globalisasi adalah suatu proses intekasi antara berbagai bangsa dan/atau masyarakat di dunia yang menimbulkan terjadinya saling pengaruh-mempegaruhi dan saling ketergantungan dalam berbagai bidang kehidupan, khususnya antara masyarakat negara maju $(=$ masyarakat 
industri) dengan masyarakat negara berkembang, termasuk Indonesia.

Pembangunan yang dimaksudkan dalam penelitian ini ialah pembangunan di Indonesia yang diartikan sebagai suatu upaya terencana yang dilakukan oleh pemerintah dengan tujuan untuk meningkatkan taraf dan kesejahteraan masyarakat di segala bidang. Pembangunan di Indonesia merhiliki wawasan nasional, regional, dan lokal yang dirancang dalam tahapan-tahapan Replplita dengan tujuan berjangka pendek, sedang/menengah, dan panjang.

Pemilihan lokasi penelitian dilakukan dengan tetap mengacu kepada ketentuan disain dan secara operasional disesuikan dengan kebijaksanaan pembangunan regional (Propinsi Maluku) dan lokal (Kotamadya Ambon).

Dalam Pola Dasar Pembangunan Daerah Kotamadya Ambon (Pelita V) yang merupakan penjabaran dari Pola Dasar Pembangunan Daerah Propinsi Maluku, antara lain ditetapkan kebijaksanaan pengembangan Kotamadya Ambon dengan membaginya menjadi tujuh sub wilay ah pengembangan dengan pusat-pusat pelayanan yang pada gilirannya akan ditingkatkan menjadi pusat pertumbuhan. Empat dari tujuh sub wilayah pengembangan itu berada dalam wilayah Kecamatan Teluk Ambon Baguala, dua di antaranya mencakup tiga desa lokasi penelitian, yakni sub wilayah Passo (meliputi Desa Passo dan Desa Batu Gong) dan sub wilayah Hutumuri.

Sub wilayah Passo dan sekitarnya sementara dikembangkan sebagai kawasan industri, pemukiman, dan pendidikan, sedangkan sub wilayah Hutumuri sementara dikembangkan sebagai kawasan pertanian, perikanan, peternakan dan pariwisata.

Dengan memperhitungkan kebijaksanaa pengembangan tersebut serta kegiatan pembangunan dewasa ini (adanya pabrik/industri) dan setelah mendengarkan saran dan pertimbangan dari pejabat agama setempat (Kepala Kanwil dan" Kepala Kantor Departemen j Agama setempat) maka para peneliti sepakat menetapkan tiga desa yang telah disebutkan di atas sebagai sasaran penelitian.

\section{SELAYANG PANDANG LOKASI PENELITIAN}

Kotamadya Ambon yang berpenduduk sebanyak 274.970jiwa, distribusi penduduk menurut agama yang dianut adalah : (1) Islam, 114.623 jiwa atau 41,69\% ; (2) Protestan, 145.507 jiwa atau 52,92 \% ; (3) Katolik, sebanyak 14.373 jiwa atau 5,23\% ; (4) Hindu, 234jiwa atau 0,08 \% (5) Budha, 139 jiwa atau $0,05 \%$, dan lainnya, 94 jiwa atau $0,03 \%$.

Daerah Kotamadya Ambon yang luasnya 377 kilometer persegi atau 2/5 dari luas pulau Ambon, terdiri dari 3 wilayah kecamatan, masing-masing : (1) Kecamatan Nusantara, (2) Kecamatan Sirimau, dan (3) Kecamatan Teluk Ambon Baguala.

Kecamatan Teluk Ambon Baguala (lokasi penelitian) terdiri dari 18 desa, dengan penduduk berjumlah 78.413 jiwa (menurut data Kantor Urusan Agama Kecamatan bersangkutan). Distribusi penduduk menurut agama yang dianut, adalah : (1) Islam, 35.597 jiwa atau 45, 
$39 \%$; (2) Protestan, 36.987 jiwa 47,17 \%

(3) katolik, 5.692 jiwa atau $7,26 \%$; (4) Hindu, 24 orang atau 0,03\% ; (5) Budha, 113 jiwa atau $0,144 \%$.

Hubungan transportasi antardesa dalam wilayah Kecamataqn Teluk Ambon Bagaula cukup lancar karena adanya jalan-jalan desa yang walaupun belum seluruhnya beraspal naumn cukup layak dilalui kendaraan beroda empat. Sedangkan hubungan antara ibukota kecamatan yakni Passo dengan ibukota Ambon sangat lancar karena dilewati oleh jalan raya negara yang beraspal mulus dan didukung oleh banyaknya kendaraan angkutan umum (mikrolet).

Tiga desa yang dipilih sebagai lokasi sasaran penelitian dalam wilayah Kecamatan Teluk Ambon Baguala masing-masing adalah : (1) Desa Passo, (2) Desa Hutumuri dan (3) Desa Batu Gong. Ketiga desa tersebut dihubungkan satu dengan lainnya oleh sebuah jalan penghubung antar desa yang beraspal. Pengaspalan jalan tersebut dilakukan dengan bantuan dua perusahaan yang mendirikan dua pabrik yakni P.T. Jati Maluku membangun pabrik kayu lapis di Desa Batu Gong, dan P.T. Anugrah Timur Sejati Permai yang mendirikan pabrik pengawetan ikan di Desa Hutumuri.

Penduduk Desa Passo berjumlah 12.145 jiwa, lebih separuh atau 50,27 \% beragama Kristen Protestan. lebih $35 \%$ beragama Islam, dan lebih $13 \%$ beragama Katolik, sedangkan selebihnya (100 orang) beragama Budha (pendatang).

Penduduk Desa Hutumuri berjumlah 3.124 jiwa terdiri dari penganut agama Islam 1.462 jiwa atau 46,35 \%, Kristen Protestan 1.692 jiwa atau 53,65 \%. Sedangkan penduduk Desa Batu Gong berjumlah 2.057 jiwa, terdiri dari umat Islam 1.598 jiwa atau lebih $77 \%$, umat Kristen Protestan 288jiwa atau $14 \%$, umat Katolik 167 orang atau $8 \%$ lebih, dan umat Hindu 4 orang.

Penduduk asli yang mendiami ketiga desa adalah orang Ambon (yang menghuni pulau-pulau Ambon, Hitu, Haruku, Saparua, dan Seram Barat). Penduduk pendatang yang relatif banyak jumlahnya ialah orang Buton, Bugis Makassar, dan Jawa; yang tersebut pertama umumnya bekerja sebagai petani pemilik cengkeh, yang kedua lebih cenderung menekuni perdagangan dan jualjualan, sedangkan yang tersebut terakhir umumnya bekerja sebagai karyawan pabrik dan pengusaha waning makan. Ketiga kelompok orang pendatang hampir seluruhnya memeluk agama Islam.

Matapencaharian utama penduduk asli ketiga desa lokasi penelitian adalah bertani cengkeh, sayur-sayuran, dan jambu mente. Kondisi lahan pertanian mereka tidak memungkinkan mereka bercocok tanam (padi), sehingga makan pokok tersebut didatangkan dari luar daerah/propinsi.

Di samping bertani (perkebunan), penduduk ketiga desa memiliki pekerjaan lain atau pekerjaan sampingan yang agak bervariasi. Penduduk Desa Hutumuri, selain bertani mereka juga bekerja sebagai nelay an yang mensuplai pabrik pengawetan ikan setempat. Sedangkan penduduk Desa Batu Gong, selain bertani, juga ada yang bekerja sebagai karyawan pabrik kayu lapis setempat. Adapun penduduk Desa Passo, memiliki mata pencaharian yang beragam di samping petani, seperti nelayan, pedagang, pegawai negeri dan ABRI; buruh 
pabrik (pabrik kayu lapis di Batu Gong), dan pelayan jasa, baik di Passo sendiri (Ibukota Kecamatan T. A. Baguala) maupun di kota Ambon sebagai kota pusat pemerintahan, perdagangan, dan penyediaan jasa di wlilayah Kotamadya Ambon dan Propinsi Maluku.

Untuk kepentingan pelayanan kehidupan beragama penduduk, di tiga desa lokasi penelitian tersedia rumah ibadah paling kurang sebuah untuk setiap agama, tokoh/pemimpin dan/atau pelayan agama, saranapenunjang kegiatan keagamaan yang bervariasi.

Walaupun terdapat sedikit perbedaan mengenai keadaan sosial ekonomi antara tiga desa lokasi penelitian, namun mereka pada umumnya telah akrab dengan tayangan-tayangan televisi (instrumen globalisasi) berkat adanya listrik masuk desa (pembangunan setempat) serta tersedianya infra struktur ekonomi yang relevan dengan ekonomi pedesaan (jalanan dan pengangkutan, perbankan, prasarana perdagangan, koperasi (K.U.D.) dan beragam pelayanan jasa).

\section{RESPON MASYARAKAT TERHADAP TREND GLOBALISASI DAN PEM- BANGUNAN"}

\section{Pengaruh globalisasi dan pemba- ngunan}

Arus globalisasi dan proses pembangunan (nasional, regional, dan lokasi) yang dialami masyarakat di lokasi penelitian menimbulkan perubahan-perubahan yang cukup berarti terhadap kehidupan masyarakat bersangkutan. Penyerapan dan penerapan teknologi modern di satu pihak serta pembangunan ekonomi di lain pihak merupakan dua faktor penting yang secara simultan mempengaruhi dan menjadi penyebab utama terjadinya perubahan-perubahan tersebut.

Wujud, arah, dan intensitas perubahan yang terjadi banyak ditentukan oleh latar belakang kondisi geografis, penguasaan sumber daya alam, kondisi sosial budaya, penguasaan ketrampilan menggunakan teknologi, wawasan dan persepsi masyarakat bersangkutan terhadap trend globalisasi dan pembangunan serta intensitas terpaan arus globalisasi.

Penyerapan teknologi yang didominasi oleh teknologi informasi dan komunikasi global melanda masyarakat secara luas. Hampir seluruh anggota masyarakat setempat memiliki dan mengakrabi instrumen teknologi informasi yang sangat populis yakni radio dan televisi. dan ditopang dengan kehadiran berbagaTjenis media penerbitan seperti surat kabar (nasional dan lokal) serta majalah.

Masyarakat setempat mengakui adanya dampak positif yang mereka rasakan dengan kehadiran teknologi informasi yakni sebagai media dan sarana untuk memperoleh informasi di samping sarana ontuk meningkatkan pengetahuan i|n wawasan serta sarana untuk memperoleh hiburan segar.

Namun demikian, mereka juga menyadari bahwa kehadiran teknologi informasi menimbulkan berbagai masalah sosial yang tidak diperhitungkan sebelumnya oleh anggota masyarakat pengguna jasa teknologi informasi tersebut. Masalah-masalah sosial yang dimaksud antara lain, ber- 
kurangnya waktu dan konsentrasi belajar anak-anak mereka di luar sekolah karena waktu sebagian besar digunakan menyaksikan acara-acara tayangan televisi yang "mengangkasa" selama tidak kurang dari 18 jam sehari. Masalah lain, terutama di kalangan remaja ialah mudah terimbasi oleh gaya hidup "globalisasi" yang selain asing bagi mereka juga tidak sesuai dengan nilainilai budaya dan ajaran agama yang mereka anut. Seperti antara lain, kecenderungan meminum minuman keras, kehidupan hurahura dan gaya ssantai, perkelahian antar kelompok, pemerkosaan, dan akhir-akhir ini telah ditemukan remaja yang mengisap gaja.

Kehadiran industri di lokasi penelitian seperti industri pengelolaan kayu lapis, industri pengawetan ikan, dan berbarengan itu digalakkan pembangunan ekonomi dengan infra strukturnya serta penjualan jasa, di satu pihak memberikan dampak positif bagi kehidupan masyarakat seperti terbukanya lapangan kerja, kesempatan memperoleh pekerjaan sampingan dan/atau beralih profesi, kemudahan melakukan mobilitas sosial yang kesemuanya dapat meningkatkan penghasilan dan kesejahteraan ekonomi masyarakat. Namun di lain pihak menyebabkan terjadinya kecenderungan baru antara alih "profesi" dari petani ke sektor jasa, harga'tanah meningkat dan fungsinya bergeser, gaya hidup konsumtif, individualistis serta materialistis, melemahnya semangat gotong royong, serta menurunnya kegiatan keagamaan berkelompok. Kecenderungan tersebut dinilai oleh sementara tokoh masyarakat sebagai dampak negatif karena merubah kemapanan kehidupan ekonomi dan hubungan sosial masyarakat menjadi transisional dan labil.

Berkaitan dengan penerapan teknologi kedokteran dalam penanganan masalah kesehatan masyarakat, tampak belum menimbulkan permasalahan di kalangan masyarakat setempat. Kehadiran PUSKESMAS dan PUSKESMAS Pembantu yang ditempatkan di ibukota kecamatan (lokasi penelitian) dengan sarana kelengkapan dan personalia (dokter dan tenaga media lainnya) sangat dirasakan manfaatnya oleh masyarakat. Penyakit malaria yang sering menimpa sebagian penduduk, secaraberangsur berkurang setelah kehadiran sarana dan fasilitas kesehatan tersebut. Pelayanan KB tidak menimbulkan kerisihan masyarakat (aseptor) yang dilayani, terutama dalam pemakaian/pemasangan alat kontrasepsi yang dipilih sendiri, karena tersedia petugas wanita (bidan dan perawat) untuk melayani aspetor yang tidak ingin dilayani petugas pria.

Bentuk-bentuk pelayanan kesehatan yang menggunakan peralatan dan teknik canggih (produk teknologi kesehatan yang canggih) seperti pencangkkokan, bayi tabung, inseminasi, bedah platik, donor darah, dan pembedahan yang rumit, tampak belum banyak dikenal masyarakat setempat karena pelayanannya belum pernah dilaksanakan di PUSKESMAS setempat, sehingga mereka tidak memberikan komentar banyak.

Pengungkapan rasa kepuasan masyarakat, demikian pula rasa keperhatinan mereka di dalam menerima dan menerapkan teknologi modern serta kebijaksanaan ekonomi pemerintah, sesungguhnya 
merupakan awal yang penting dari responsi mereka terhadap trend globalisasi dan pembangunan yang diperhadapkan kepada mereka. Responsi selanjutnya akan sangat ditentukan oleh respon awal tersebut. Sedangkan bentuk-bentuk responsi itu bervariasi, baik kuantitas dan frekuensi maupun kualitas dan intensitas, banyak tergantung pada potensi dasar yang dimiliki anggota atau kelompok masyarakat serta peluangpeluang tersedia yang dapat mereka raih/ gapai yang secara keseluruhan menentukan kesiapan mereka menghadapi dan merespon trend globalisasi dan proses pembangunan.

\section{Respon di bidang ekonomi}

Gambaran umum kondisi dan perkembangan ekonomi masyarakat di lokasi penelitian, cenderung masih bersifat ekonomi subsistensi dengan tonggak utamanya hasil-hasil pertanian. Penyerapan teknologi di bidang pertanian rakyat (yang memang hanya terbatas pada teknologi pembibitan, pengolahan hasil, dan penyuluhan) dengan hasil/komoditi pokok perkebunan (cengkeh, sayur-sayuran, dan biji jambu mente), rupanya belum dapat merubah wajah ekonomi masyarakat. Komoditi perkebunan yang menjadi "primadona" selama ini yakni tanaman cengkeh, akhirakhir ini mengalami fluktuasi harga, bahkan harganya menurun sangat derastis. Pemerintah daerah setempat (Pemda Tk I Maluku dan Pemda Tk. II Kodya Ambon) mengindentifikasikan anjloknya harga cengkeh sebagai salah satu faktor penyebab "kemiskinan masyarakat akhir-akhir ini. Hal ini dialami pula oleh masyarakat" lokasi peneli- tian (tiga desa, bahkan dua desa cukup parah yakni Desa Hutunuri dan Desa Batu Gong) yang sebagian besar penduduknya petani cengkeh.

Menghadapi sistuasi ekonomi global, termasuk kebijaksanaan pemerintah (pusat, regional, dan lokal yang terkadang dirasakan "kurang bijaksana" oleh petani), respon mereka tidak sekedar merenungi atau mengomentari perkembangan yang memperihatinkan mereka itu, melainkan mereka berupaya melakukan tidankan nyata.

Ada yang tetap bertahan pada mata pencaharian semula dengan berupaya melakukan penyesuaian dengan perkembangan dan/atau kebijaksanaan baru, sementara yang lain berupaya mencari lapangan usaha lain (usaha sampingan) di samping tetap menekuni mata pencaharian lama. Namun tidak kurang pula yang terpaksa "beralih profesi" mengganti pekerjaan lama dengan pekerjaan baru yang dianggap lebih prospektif, terutama yang dapat memberikan kontribusi berarti dalam upaya mempertahankan kelanjutan hidup.

Sektor usaha alternatif yang banyak dijadikan sasaran penduduk setempat ialah, sektor jasa. Diimaksudkan dengan sektor jasa di sini ialah pekerjaan sebagai karyawan di instansi dan perusahaan, tenaga honorarium, buruh harian serta tenaga lepas. Sektor ini banyak menampung tenaga.dari lokasi penelitian yang umumnya bukan tenaga profesional. Sebagian menemukan pekerjaan baru tersebut di kota Ambon dan sebagian pula di dalam wilayah Kecamatan Teluk Ambon Baguala saja. Kelancaran hubungan transportasi (darat dan laut) antara lokasi penelitian dengan desa-desa 
sekitarnya dan dengan kota Ambon, sangat mendukung pelaksanaan kegiatan mereka pada sektor/lapangan usaha alternatif baru itu.

Demikianlah antara lain sikap dan tindakan respon penduduk lokasi penelitian menghadapi atau menanggapi perkembangan ekonomi global yang telah menyentuh kehidupan perekonomian mereka. Pada mulanya respon mereka lebih terdorong oleh rasa keperihatinan akan eksistensi mereka ; yakni bahwa arus globalisasi ekonomi akan membuyarkan sistem ekonomi mereka yang lebih bersifat ekonomi pedesaan yang mandiri.

Namun kemudian mereka menyadari bahwa globalisasi ekonomi tidak akan bisa dibendung dalam suasana kehidupan yang semakin transparan, melainkan harus diterima sebagai suatu perkembangan wajar dari tingkat kemajuan ilmu pengetahuan dan teknologi. Yakni dengan memberikan jawaban/respon yang relevan, diawali dengan perubahan pola pikir dan penegasan persepsi bahwa dalam ekonomi global, sumber daya yang paling penting bukanlah yang datang dari tanah melainkan yang bersumber pada diri manusia itu sendiri (sumber daya manusia).

\section{Respon di bidang sosial budaya}

Arus globalisasi yang melanda kehidupan masyarakat pedesaan, sebagian besar melalui penyerapan jasa teknologi informasi dan komunikasi, terutama melalui penayangan dan siaran televisi. Bersamaan dengan masuknya film di pedesaan kedua media menyebarkan citra yang sama yakni citra dan pola gaya hidup global yang didominasi duniabarat, menyelinap di selasela kehidupan masyarakat desa yang pada umumnya belum siap betul menerimanya.

Wujud konkrit gaya global yang banyak ditayangkan di televisi dan film didominasi oleh " $3 \mathrm{f}$ ' yakni singkatan dari: food $=$ makanan./as/i/on = kebiasaan atau mode termasuk bentuk pakaian dan cara memakainya, dan fun=kesenangan/hiburan termasuk rekreasi/wisata." Lewat televisi gaya hidup global tersebut diramu dan ditayangkan dalam bentuk informasi, penampilan, dan hiburan, disaksikan oleh pirsawan yang pada umumnya terdiri dari anak-anak dan remaja yang memang sementara dalam proses mencari "identitas diri".

Masyarakat penduduk lokasi penelitian menyadari pengaruh negatif yang ditimbulkan oleh arus informasi global yang telah menggejaladalamkehidupan parakaum remaja dan mewujud berupa antara lain kecenderungan minuman-minuman keras, kehidupan hura-hura dan santai, pergaulan bebas pria dan wanita, perkelahian antar kelompok dan belakang ini ditemukan remaja yang telah ketagihan mengisap ganja.

Selain itu masyarakat lokasi penelitian menyadari pula bahwa bagaimana pun arus globalisasi yang instrumennya telah hadir di tengah-tengah mereka, bahkan telah merupakan bagian dari kebutuhan keseharian mereka, tidak mungkin lagi dibendung. Lagi pula mereka telah merasakan manfaat atau dampak positifnya.

Rasa keprihatian masyarakat terhadap dampak negatif arus globalisasi di satu pihak serta kebutuhan akan manfaatnya yang telah mereka rasakan di lain pihak mendorong 
timbulny a inisiatif mereka melakukan upay a preventif agar dampak negatif yang lebih jauh dapat dihindari, setidaknya dapat dikurangi.

Bentuk-bentuk kegiatan masyarakat di lokasi penelitian yang dapat dianggap respon mereka di bidang sosial budaya bermacam-macam. Ada yang berupa upaya individual, dan ada pula berbentuk kegiatan kelompok. Pendekatan yang digunakan juga bermacam-macam ; ada yang bersifat konvensional dan ada pula yang kontemporer. Bahkan ada yang mene-rapkan kedua pendekatan secara bergantian dan/atau secara simultan.

Respon yang berbentuk kegiatan individual antara lain dengan melakukan pengawasan intensif terhadap anak dalam memanfaatkan instrumen globalisasi yang dimiliki atau yang dapat digunakan, di samping memberikan bimbingan dan contoh tentang sikap dan tingkah laku responsif yang wajar terhadap dampak negatif "3 f".

Upaya individual lain ialah mendorong dan mengarahkan kreatifitas anak serta memberikan peluang kepada mereka untuk aktif mengambil bagian dalam berbagai kegiatan sosial yang konstruktif. Dan yang terpenting ialah memberikan peluang kepada anak-anak untuk menikmati pendidikan formal/sekolah dan keterampilan yang relevan dengan kebutuhan nyata pembangunan, terutama pembangunan daerah mereka sendiri.

Respon yang bersifat kegiatan kelompok antara lain mengaktifkan dan memberikan peranan yang lebih efektif kepada organisasi dan/atau lembaga-lembaga sosial yang ada, baik tradisional maupun artifisial/bentukan baru.

Lembaga tradisional yang mendasar ialah kesatuan kekerabatan yang disebut fam atau disebut pula marumah.

Matarumah merupakan kesatuan adat yang anggota-anggotanya terdiri dari lakilaki dan perempuan yang belum kawin dan para isteri dari laki-laki yang sudah kawin dalam lingkup keluarga dekat, atau merupakan klen-kecil patrilineal. Lingkup kekerabatan yang lebih luas dari matarumah ialah soa yang merupakan kumpulan dari matarumah-mataruman asli keturunan dari keempat sumber (nenek), jadi merupakan sistem kekerabatan yang bilateral. Di Desa Passo (salah satu desa lokasi penelitian) terdapat 3 kelompok kekerabatan soa, sedangkan di Hutumuri (desa lokasi penelitian) terdapat 5 soa dengan jangkauan wilayah meliputi dengan Batu Gong ( $\mathrm{j}^{\mathrm{a}} \mathrm{g}^{\mathrm{a}}$ salah satu desa lokasi penelitian).

Matarumah dan soa mempunyai peranan penting dalam mengatur perkawinan warganya yang menganut sistem eksogami (perkawinan di luar klen). Peranan kedua lembaga kelihatan menonjol akhir-akhir ini sehubungan dengan seringnyaterjadi kawin lari.

Sistem kawin lari cenderung menjadi pilihan terbanyak pasangan muda-mudi yang ingin membentuk rumah tangga, karena beberapa alasan : (1) untuk menghindari prosedur adat yang berliku-liku dengan memakan waktu lama dan biaya banyak ; (2) baik orang tua lelaki maupun orang tua perempuan sama-sama lebih suka memilih cara ini untuk mengurangi harta kekayaan yang harus dikeluarkan bila 
menempuh perkawinan biasa (kawin minta); dan (3) cara perkawinan ini mempunyai aturan-aturan adat yang berarti memang diantisipasi oleh adat setempat.

Akhir-akhr ii kawin lari cenderung menjadi pilihan umum pasangan mudamudi yang telah berikrar akan mengikat janji dengan tali perkawinan. Kecenderungan itu dapat dipandang sebagai rangkaian akibat pengaruh dari gaya hidup global yang telah melanda kehidupan sebagian kaum remaja di lokasi penelitian. Dan untuk mengantisipasinya masyarakat mengaktifkan peranan sistem kekerabatan lokal yakni matarumah dan soa.

Sistem kawin lari berlaku bagi semua golongan agama di lokasi penelitian. Hanya bagi umat Islam, berlaku pula ketentuanketentuan sesuai dengan hukum Islam, antara lain kewajiban membayar mahar (mas kawin), ada wali dan saksi serta ada ijabkabul (pernyataan lisan untuk saling menerima), serta menurut ketentuan dan prosedur yang berlaku (sesuai yang diatur dalam Undang-Undang Perkawinan dan peraturan-peraturan yang menyertainya).

Lembaga (sosial-budaya) tradisional lainnya yang juga tetap difungsikan, bahkan semakin dikembangkan fungsi dan peranannya dalam mengatur hubungan-hubungan sosial di lokasi penelitian ialah pranata sosial yang disebut pela. Fungsi pela padamulanya ialah untuk mempersatukan wargawarga dari dua desa atau lebih berlatar belakang rasa solidaritas dan rasa senasib sepenggungan pada masa lampau sebagai akibat adanya kontak dengan daerah atau kekuasaan lain. Pela dibentuk melalui sumpah persahabatan yang unik dan begitu dipercayainya oleh pihak yang terlibat sehingga berakibat vatal bila ketentuanketentuannya dilanggar. Karena itu pranata sosial ini tetap dipelihara masyarakat sampai sekarang.

Anggota pela tidak dibatasi oleh perbedaan agama. Penduduk Desa Passo (lokasi penelitian) sebagian besar memeluk agama Kristen mengadakan ikatan pela dengan penduduk Desa Batu Merah di Kecamatan Sirimau (dekat kota Ambon) yang sebagian besar menganut agama Islam. Demikian pula Desa Hutumuri (lokasi penelitian) dengan penduduk mayoritas menganut agama Kristen Protestan mengadakan ikatan pela dengan Desa Tamilou di Seram dan Desa Sirisori di Saparua.

Kewajiban-kewajiban yang mengikat masyarakat peserta hubungan pela, antara lain saling bantu-membantu serta bergotong-royong dalam pembangunan, seperti pembangunan balai desa, gereja, mesjid, dan sekolah. Selain itu mereka wajib saling membantu memberikan makanan (sagu) bagi yang memang memerlukan, wajib menerima anggota sepela yang ingin menginap di rumah. Mereka juga tidak boleh saling bermusuhan, saling menimbulkan kesusahan serta kesulitan. Bahkan salah satu jenis pela (yakni pela keras) melarang anggota-anggotanya mengadakan hubungan perkawinan, dan bila larangan itu dilanggar "berakibat vatal" tidak saja bagi si pelanggar tetapi juga bagi anggota-anggota lain dalam satu pela. Jenis pela ini juga mewajibkan anggotanya saling membantu dalam peperangan, bilakelompok sepelanya diserang.

Tokoh adat dan pemuka masyarakat setempat, dewasa ini berupaya mengem- 
bangkan fungsi dan meningkatkan peranan pela, antara lain dengan mengupayakan ikatan serupa pela di dalam lingkungan desa sendiri dan/atau mengembangkan kegiatannya sesuai kebutuhan pembangunan setempat, atau memperluas ikatan pela dengan desa-desa lain di sekitarnya sesuai kebutuhan.

Selain melalui lembaga/organisasi tradisional, upaya respon dan antisipasi di bidang sosial budaya dilakukan pula, oleh masyarakat lokasi penelitian, melalui organisasi sosial artifisial/bentukan baru. Seperti antara lain mengaktifkan (anggota) karang taruna, pramuka gugus depan, organisasi/perkumpulan olah raga ; juga melalui kelompok kesenian seperti paduan suara, band remaja, yang semuanya tersedia di lokasi penelitian.

Demikian antara lain upaya-upayayang dilakukan masyarakat di lokasi penelitian dalam rangka membina dan mengarahkan kegiatan anak-anak dan generasi pelanjut mereka. Upaya mereka itu dapt dipandang sebagai respon dan antisipasi mereka terhadap perkembangan kehidupan yang semakin mengarah ke globalisasi. Upayaupaya mereka tersebut tidak saja didukung oleh pemerintah tetapi juga pemerintah melalui unit-unit kegiatannya memberikan peluang serta turut membina pengembangan upaya-upaya masyarakat tersebut. Dengan lain perkataan bahwa respon masyarakat pada gilirannya mejadi input bagi pemerintah atau pelaksana pembangunan dalam rangka pelaksanaan pembangunan lebih lanjut.

\section{Respon dan antisipasi di bidang agama}

Sebagaimana halnya di bidang sodial budaya, upaya-upaya masyarakat lokasi penelitian membina kehidupan beragama mereka sendiri di tengah-tengah terpasan arus globalisasi, bermacam-macam. Ada yang bersifat indidual dan ada yang bersifat kelompok/organisasi. Ada yang bersifat tradisional dan ada yang bersifat kontemporer, bahkan ada yang menggunakan kedua-duanya, baik secara bergantian maupun secara simultan. Upaya-upaya tersebut merupakan respon dan antisipasi masyarakat menghadapi arus globalisasi dan perkembangan iptek yang diduga (bahkan telah dirasakan gejalanya) mempengaruhi kehidupan beragama mereka.

Penduduk lokasi penelitian (tiga desa dalam satu kecamatan), menurut data pada Kantor Urusan Agama Kecamatan Teluk Ambon Baguala akhir tahun 1992, berjumlah 17.626 jiwa atau 23,35\% dari seluruh penduduk kecamatan. Distribusi penduduk menurut agama yang dianut adalah :

(1) Islam 7.365 jiwa; (2) Kristen Protestan, 8.085jiwa; (3) Kristen Katolik, 1.802jiwa ; (4) Budha, 100 jiwa; dan (5) Hindu, 4 jiwa.

Kecuali dua agama yang disebut terakhir, tiga agama lainnya memiliki sejumlah sarana dan kelengkapan yang digunakan dalam rangka pelaksanaan ibadah dan kegiatan keagamaan lainnya sesuai dengan kewajiban dan ajaran agama bersangkutan. Sarana-sarana yang dimaksud meliputi rumah ibadah (mesjid dan gereja), sekolahsekolah agama (status swasta agama), pemuka-pemuka agama (imam, khatib, modin, guru mengaji, guru agama, pendeta, penatua, syamas, dan lain-lain). 
Keberadaan sarana-sarana kehidupan beragama tersebut pada umumnya tidak berkaitan secara kausal dengan dampak negatif dari arus globalisasi terhadap kehidupan beragama mereka. Artinya, kehadiran dan fungsionalisasi sarana itu hampir bersamaan dengan kehadiran agama-agama bersangkutan di lokasi penelitian, sejak berabad-abad yang lalu, jauh sebelum pemeluk agama bersangkutan mengenal televisi, lama sebelum lapangan terbang Pattimura serta jalan-jalan penghubung desa dan kota beraspal mulus. Walaupun fungsi yang diberikan kepada sarana kehidupan beragama tersebut, waktu itu, masih bersifat dasar, namun demikian hal itu telah cukup mengungkapkan identitas masyarakat setempat sebagai pemuluk agama yang taat.

Pembangunan yang dilaksanakan pemerintah orde baru yang memang bertujuan untuk menciptakan kesejahteraan lahir dan batin masyarakat, pada gilirannya mempengaruhi keberadaan sarana-sarana keagamaan yang ada. Pengaruh itu membawa perubahan kuantitas dan kualitas, baik fisik maupun fungsi sarana -sarana keagamaan tersebut.

Wujud perubahan-perubahan dimaksud di atas antara lain, dalam hal fisik bangunan, berupa : perbaikan bangunan dan penambahan ruangan, penambahan jumlah bangunan fisik seperti rumah-rumah ibadah dan bangunan sekoolah. Penambahan itu dilakukan, selain untuk memenuhi/menampung kebutuhan warga jamaah yang semakin bertambah jumlahnya (baik karena kelahiran maupun karena perpindahan penduduk), juga untuk keperluan pengem- bangan fungsinya seperti, ruang perpustakaan dan ruang belajar/mengaji untuk mesjid, ruang perpustakaan, aula, dan mushallah untuk sekolah agama.

Perubahan juga terjadi pada organisasi dan/atau lembaga keagamaan, berupa pengembangan struktur dan fungsi organisasi/lembaga yang ada serta pembentukan organisasi/lembaga baru.

Di kalangan umat Islam setempat, organisasi tradisional seperti pengurusan mesjid, dikembangkan struktur dan fungsinya, walaupun belum seperti pengembangan fungsi mesjid di kota-kota yang bidang kegiatannya bermacam-macam. Pengajian tradisional yang dilaksanakan di rumah-rumah guru mengaji, dikembangkan menjadi Taman Pengajian Alqur'an (T.P. A.) yang pelaksanaannya dilakkan di tempattempat tertentu. Pengurusan zakat fltrah dan zakat harta (penerimaan dan pembagian zakat) yang selama berabad-abad ditangani oleh pejabat agama lokal yakni yakni imam dan pembantu-pembatunya, kini penanganannya diorganisasikan melalui Badan Amil Zakat (B.A.Z.) yang strukturnyaberjenjang naik (tingkat desa sampai ke tingkat propinsi).

Selain itu, muncul organisasi baru seperti majelis taklim, remaja mesjid, kelompok-kelompok arisan yang anggotaanggotanya pada umumnya ibu dengan agenda acara tetap secara berkala pengajian/ ceramah agama.

Taman Pengajian Alqur'an (T.P.A.) adalah juga termasuk organisasi artifisial atau bentukan baru walaupun sebagian merupakan pengembangan dari pengajian tradisional.Organisasi keagamaan lama 
yang level nasional seperti Nahdatul 'Ulama (N.U.), Serikat Islam (S.I.), Muhammadiyah yang pernah menjangkau desa-desa Islam di lokasi penelitian, kini tidak lagi tampak secara organisasi walaupun secara persepsi dan aspirasi masih jelas tampak pengaruhnya di kalangan masyarakat.

Di kalangan umat Kristen (Protestan dan Katolik) organisasi keagamaan mereka di tingkat desa, khususnya di lokasi penelitian, yang tampak menonjol ialah organisasi gereja yakni majelis jemaat setempat. Organisasis sosial keagamaan yang ada dan barangkali dapat dianggap organisasi bentukan baru (artifisial) ialah remaja gereja, dan organisasi wanita (pelayan wanita). Yang tampak aktivitasnya ialah di desa Passo (ibukota Kecamatan T.A. Baguala) sedangkan di dua desa lainny a (lokasi penelitian) kurang tampak kegiatannya.

Namun demikian aktivitas keagamaan di kalangan umat Kristen cukup padat yang menyebabkan pemuka agama (pendeta, penatua, dan syamas) cukup sibuk melayani bimbingan keagamaan umat/ jemaatnya. Seperti pelayanan ibadat jemaat, pelayanan pembaptisan kudus, perjamuan kudus, peneguhan sidi, pemberkatan nikah, pengembalaan, pemberitaan Injil, dan pembinaan warga gereja. Ibadat jemaat sendiri cukup beragam, seperti kebaktian hari minggu, kebaktian hari-hari raya gerejawi, kebaktian rumah tangga, kebaktian pengucapan syukur, kebaktian doa, kebaktian penyegaran iman, dan kebaktian-kebaktian lain yang diatur oleh majelis gereja.

Melalui sarana dan aktivitas keagamaan tersebut di atas para pemuka/pe- mimpin masing-masing agama berupaya meningkatkan pemahaman dan pengetahuan agama para penganutnya, memberikan pelayanan kepentingan keagamaan, mendorong semangat beramal termasuk keikutsertaan mereka dalam kegiatan pembangunan. Di samping itu, melalui sarana dan aktivitas keagamaan tersebut, para pemimpin agama maing-masing membimbing jemaat/jamaahnya marespon dan mengantisipasi trend globalisasi dan proses pembangunan yang sementara mereka hadapi dewasa ini.

Respon agama atau umat beragama secara garis besarnya diarahkan kepada dua tujuan yakni pencegahan dan pembinaan, mencegah dampak negatif yang lebih jauh dan menyadarkan yang telah terkena dampak negatif serta membina lebih lanjut,baik yang telah mengalami proses penyadaran maupun yang belum terimbasi/terkena dampak negatif.

Bentuk-bentuk respon mereka, secara individual antara lain mengintensifkan pengawasan orang tua terhadap anak-anak mereka, baik dalam rangka pelaksanaan ibadah maupun pencegahan terhadap pelanggaran ajaran agama. Secara kelompok antara lain memberikan peluang dan mendorong anak-anak mereka aktif dalam kegiatan sosial keagamaan, seperti perkumpulan remaja (remaja mesjid dan remaja gereja) perkumpulan kesenian bermanfaat agama (grup kasidah), kegiatan pembinaan berkala melalui acara-acara kebaktian dan pengajian serta ceramah-ceramah keagamaan, dan kegiatan-kegiatan sosial keagamaan lokal. Selain itu, anak-anak remaja dilibatkan pula dalam pelaksanaan acara- 
acara peringatan hari keagamaan seperti Natal, Maulid dan Isra' Mi'Raj Nabi Muhammad, Musabaqah Tilawatil Qur'an, dan pesta Pespa-rani. Bahkan kaum remaja dari semua agama yang ada, sering dilibatkan bersama-sama (sebagai panitia) dalam pelaksanaan acara-acara peringatan hari besar keagamaan dari agama tertentu.

Dalam rangka pembinaan umat beragama di lokasi penelitian, pemuka dan pemimpin dua agama yang besar penganutnya yakni Kristen Protestan dan Islam dewasa ini mengorientasikan program pembinaan kepada pola pembinaan dan pengembangan yang telah dicanangkan pemimpin mereka di tingkat propinsi. Pembinaan umat Kristen Protestan diorientasikan pada pola pembinaan dan pengembangan yang dicanangkan oleh Pengurus Klasis Gereja Protestan Maluku (G.P.M.) Pulau-Pulau Ambon, meliputi tiga bidang yakni: (1) Iman, (2) Ilmiyah, dan (3) Sosial Budaya,

Di kalangan umat Islam, program pembinaan dan pengambangan lebih diorientasikan pada pola pembinaan yang dicanangkan organisasi-organisasi keagamaan di tingkat propinsi yakni Majelis Ulama Indonesia (MUI), Yayasan Al Hilal dan Organisasi Muhammadiyah. Mereka sepakat mengorientasikan pembinaan dan pengeambangan di bidang pendidikan formal dengan mendirikan sekolah-sekolah agama Islam dari tingkat Sekolah Dasar sampai Sekolah Menengah Atas serta mendirikan pesantren (sebagai cabang pesantren Al Hilal di kota Ambon). Di lokasi penelitian, program pembinaan masih dalam tahap awal yakni penyediaan sarana fisik.

Pengurus mesjid setempat, sebagai salah satu lembaga keagamaan tertua dan mapan, dalam upaya meningkatkan pelayanan dan pembinaan kepada jamaahnya, berupaya memperluas jangkauan fungsi serta menambah frekuensi kegiatan. Yakni di samping sebagai tempat beribadah (fungsi ibadah) juga difungsikan sebagai tempat pendidikan sepeti tempat pelaksanaan T.P.A., dan pengajian berkala, tempat pembinaan generasi muda (melalui kegiatan remajamesjid), pengadaan perpustakaan mesjid, serta kegiatan sosial keagamaan lainnya yang pelaksanaannya tidak mengganggu pelaksanaan fungsi utama mesjid sebagai tempat beribadah.

Pemimpin lokal umat Islam di lokasi penelitian yang cukup dihormati dan selalu dibutuhkan keberadaannya oleh umat Islam setempat, terutama dalam setiap prosesi tradisional yang bernafaskan keagamaan ialah imam dan pembantu-pembantunya, seperti khatib dan modin. Pola kehidupan keagamaan umat Islam setempat yang cenderung bersifat tradisional, tetap menempatkan pemimpin lokal keagamaan tersebut pada posisi sentral. Mereka selalu menjadi acuan masyarakat, baik dalam memimpin ibadah maupun memimpin prosesi-prosesi tradisional masyarakat yang berkaitan dengan peristiwa lingkaran hidup yang memang telah menjadi tugas mereka secara turun-temurun selama berabad-abad keberadaan Islam di daerah mereka. Prosesiprosesi tradisional yang dimaksud meliputi antara lain peristiwa-peristiwa kelahiran, perkawinan, kematian, syukuran, dan lainlain yang rangkaian acaranya berbaur 
dengan acara-acara yang bersifat keagamaan, antara lain pembacaan kitab barzanji, pembacaan doa, yang dipimpin langsung oleh pejabat agama lokal tersebut.

Dewasa ini, pejabat agama lokal tersebut merasakan kesulitan dalam hal kehidupan sosial-ekonomi mereka. Biaya hidup mereka selama ini memang bersumber dari masyarakat dalam kaitan dengan pelayanan keagamaan yang diberikan. Sumber lain yang secara turun temurun memberikan kontribusi berarti bagi kehidupan sosial ekonomi mereka yakni perolehan dari pengurusan zakat fitrah dan zakat harta umat Islam setempat, kini tidak dapat lagi mereka harapkan karena pengurusannya telah ditangani oleh lembaga khusus yang dibentuk pemerintah yakni Badan Amil dan Zakat (B.A.Z.).

Mereka menghadapi dilemma, di satu pihak, keberadaan mereka tetap dibutuhkan masyarakat bahkan posisi mereka merupakan ujung tombak pembinaan kehidupan beragama umat Islam di desa. Namun di lain pihak kelangsungan hidup mereka terdesak karena tidak adanya lagi sumber pendapatan nyata, sedangkan mereka tidak memiliki ketrampilan khusus untuk "berprofesi ganda" atau beralih profesi.

Mengingat besarnya peranan pejabat agama lokal tersebut dalam pembinaan kehidupan beragama umat Islam di desadesa maka seyogianya mereka mendapat perhatian pembinaan. Pembinaan dalam arti peningkatan pengetahuan dan keterampilan pelaksanaan tugas serta pembinaan dalam arti penyediaan sumber jaminan hidup. Mereka mengharapkan agar pengelolaan zakat dikembalikan kepada mereka, setidaknya mereka ditunjuk selaku amil tetap di desa masing-masing, sehingga dari perolehan mereka selaku amil zakat, dapat membiayai hidup dan aktivitas mereka memimpin dan melayani kepentingan umat Islam."

\section{KESIMPULAN}

\section{Kesimpulan}

Arus globalisasi (dalam bentuk teknologi modern) serta pembangunan regional dan daerah (dengan orientasi pembangunan ekonomi) yang menyentuh kehidupan masyarakat di lokasi penelitian, menimbulkan perubahan-perubahan berarti terutama dalam bidang-bidang ekonomi, sosial budaya, dan agama.

Responsi masyarakat terhadap perubahan-perubahan itu, secara umum menunjukkan persamaan-persamaan, walaupun secara individu tampak ada perbedaan yang kadang signifikan. Perbedaan terjadi disebabkan oleh antara lain karen adanya perbedaan potensi yang dimiliki (semangat/ etos kerja, potensi sumber daya manusia, penguasaan sumber daya alam), peluangpeluang tersedia yang dapat mereka raih, serta intensitas arus globalisasi yang menerpa kehidupan mereka.

Masyarakat lokasi penelitian, dalam upaya menggeluti kehidupan sosial - ekonomi mereka yang mau tidak mau terkena terpaan arus globalisasi, pada umumnya masih tetap mengindahkan nilai-nilai budaya dan agama yang mereka anut, bahkan menjadikannya sebagai rujukan normatif dalam menentukan pilihan orientasi dan antisipasi masa depan mereka. 


\section{Saran-saran.}

(1) Kondisi dan perkembangan ekonomi masyarakat di lokasi penelitian yang cenderung masih bersifat ekonomi subsistensi, menuntut perlunya kearifan pihak penentu kebijaksanaan untuk menerapkan kebijakan ekonomi (dalam rangka ekonomi global) yang lebih berorientasi pada pembinaan dan pemberian peluang bagi masyarakat daripada perolehan keuntungan material semata. Dalam hubungan ini Koperasi Unit Desa (K.U.D) perlu dibina terus dan ditingkatkan peranannya.

(2) Upaya masyarakat untuk merefungsionalisasikan pranata budaya lokal yakni pela dalam rangka mengantisipasi pengaruh globalisasi di bidang sosialbudaya perlu mendapat dukungan dari pihak penentu kebijakan.

(3) Keberhasilan pembinaan umat beragama yang dilakukan pemuka dan/ atau pemimpin masing-masing agama, pada gilirannya dapat menumbuhkan rasa "kebanggaan" selaku pemeluk agama tertentu. Pada tahap ini, "sentimen keagamaan" sering mudah terpancing dan sering dimanfaatkan oleh pihak tertentu untuk kepentingan tertentu pula. Karena itu perlu diantisi- pasi seawal mungkin berbarengan dengan upaya pembinaan intern umat beragama itu sendiri. Dalam hal ini, penerapan aturan pela (setelah dimodifikasi untuk keperluan ini) mungkin sangat membantu.

(4) Tradisi-tradisi sosial keagamaan yang telah dilaksanakan masyarakat secara turun-temurun, perlu dibina dan diarahkan agar relevan dengan arah kebijaksanaan pembangunan di bidang agama. Bahkan dapat dimanfaatkan sebagai umpan balik untuk membina kehidupan peragama masyarakat. Khusus bagi kalangan umat Islam setempat dengan pola kehidupan sosial keagamaan yang cenderung konvensional, figur dan/atau tokoh agama yang paling sentral ialah imam dan para pembantunya \{khatib, modin, dan lain-lain). Posisi mereka merupakan "ujung tombak" pembinaan kehidupan beragama masyarakat di pedesaan. Karena itu sangatlah bijaksana apabila mereka mendapat pembinaan dari pihak yang berkompeten ; baik pembinaan pengetahuan, keterampilan, dan wawasan yang berkaitan dengan pelaksanaan tugas selaku pelayanan syara' maupun pembinaan dalam hal kehidupan sosialekonomi mereka yang tampaknya memperihatinkan. 


\section{CA T A T A N}

1) Tulisan ini diangkat dari Laporan Penelitian penulis (1993/1994) dengan judul: Antisipasi Agama terhadap Trend Globalisasi Pembangunan Regional dan Lokal di Propinsi Maluku (Studi Kasus di Kecamatan Teluk Ambon Baguala Kodya Ambon). Makalah laporannya telah diseminarkan di Balai Penelitian Lektur Keagamaan Ujung Pandang (1993) dan di Badan Litbang Agama Dep. Agama (1994).

2) Dimaksudkan dengan disain di sini ialah disain penelitian tersebut 1) di atas.

3) Angka-angka data lokasi penelitian yang dicantumkan di atas berdasarkan keadaan akhir tahun 1992. Data tersebut dikutip dari: (1) Laporan Tahunan 1992 Kantor Statistik Kotamadya Ambon ; (2) Laporan Tahunan 1992 Kantor Departemen Agama Kotamadya Ambon ; (3) Kecamatan Teluk Ambon Baguala dalam Angka, Kantor Statistik. Kec. T.A. Baguala, 1992 ; dan (4) Dokumen dan papan potensi desa lokasi penelitian. Sedangkan data lainnya disari dari hasil wawancara penulis dengan para pejabat yang terkait.

4) Informasi tentang responsi masyarakat terhadap trend globalisasi dan pembangunan, diramu dari hasil wawancara penulis dengan tokoh/pemuka/ anggota masyarakat di lokasi peneli- tian.

5) Ekonomi "3 f" (food, fashion, fun), dikutip dari John Naibith \& Patricia Aburdene, "Negatends 2000", dalam Warta Ekonomi (Jakarta : Penggebu WartaEkonomi, 1990), Nomor01/1990, hal. 20.

6) Hasil wawancara dengan J.B. Sarimanella dan G. Rinsampassy di Kantor Desa Passo, tgl. 6 Oktober 1993.

Mengenai lembaga tradisional masyarakat di Ambon (seperti fam, matarumah, soa, dan pela), dapat dibandingkan dengan Subiyakto, "Kebudayaan Ambon", dalam Kontjaraningrat (Ed.), Manusia dan Kebudayaan di Indonesia (Jakarta : Djambatan, 1988), cet. keduabelas, hal. 173 - 189. Juga dapat dibandingkan dengan Frank L. (cooley, "Allang : Sebuah Desa di Pulau Maluku, dalam Kuntjaraningrat (Ed.), Masyarakat Desa di Indonesia (Jakarta: Lembaga Penelitian Fakultas Ekonomi UI, 1984), cet. ke-2, hal. 166 - 193.

7) Informasi tentang peranan imam dan pembantu-pembantunya dalam kehidupan beragama masyarakat (Islam) di lokasi penelitian, diperoleh dari hasil wawancara dengan Kepala antor Urusan Agama Kecamatan T.A. Baguala pada tanggal 5 Oktober 1993 di kantornya ; juga hasil wawancara dengan pemuka Islam setempat dan dengan para imam itu sendiri. 
DAFTAR BACAAN

Bappeda Kodya Tingkat II Ambon

1989 Pola Dasar Pembangunan Daerah Kotamadya Daerah Tingkat II Ambon. Ambon.

Bappeda Tingkat I Maluku

1993 Pembangunan Daerah Tingkat I Propinsi Maluku Pelita VI Propinsi Maluku (Draft 15, 9 September 1993). Ambon.

Cooley, Frank

1984 Alang sebuah Desa di Pulau Ambon. Masyarakat Desa di Indonesia. Redaksi Kontjaraningrat, Lembaga Penerbit Fakultas Ekonomi Universitas Indonesia, halaman 166 - 193.

Kantor Departemen Agama Kodya Ambon 1993 Laporan Tahunan 1992.
Kantor Urusan Agama Kecamatan Teluk Ambon Baguala

1993 Laporan Tahunan 1992

Kotamadya Ambon, Kantor Statistik

1991 Kecamatan T.A. Baguala dalam angka. Ambon.

Pat. Badrun

1993 Pengkajian Antisipasi Agama terhadap Trend Globalisasi Pembangunan Regional dan Lokal di Kec. T.A. Baguala Kodya Ambon Propinsi Maluku. Laporan Penelitian 1994

Subyakto

1988 Kebudayaan Ambon. Manusia dan Kebudayaan di Indonesia. Redaksi Koentjaraningrat, Jakarta, Penerbit Djambatan, cetakan keduabelas, halaman 173 - 189.

Sudjangi, dkk.

1993 Rangkuman Penelitian Tentang Antisipasi Agama terhadap Trend Globalisasi Pembangunan Regional dan Lokal (Tahap Pertama). Jakarta, Proyek Penelitian Keagamaan Badan Litbang Agama Departemen Agama. 